\title{
Communicating the 'Migrant' Other as Risk Space, EU and Expanding Borders
}

\author{
Ibrahim, Yasmin (Queen Mary University of London) \\ Howarth, Anita (Brunel University London)
}

Forthcoming: Journal of Risk Research (accepted 26.03.2017)

\begin{abstract}
Forced migration and border spaces as fault lines posing risks to society through the notion of 'Othering', remain under-explored in risk literature. With Europe facing its biggest humanitarian crisis with forced migration and displacement due to conflict zones, the borders of the European Union have received renewed attention in media. Refugees and the displaced are often depicted as 'migrants' and are seen as transgressing borders as illegitimate entities. Although increasing attention has been paid to border patrol and issues of securitization since 9/11, the 'migrant' body as 'risky body' in political and policy discussions is underconceptualised and theorised in risk literature. We examine political discourses of the UK government to discern how the migrant and the expanding borders of the EU are framed as forms of societal and economic risk and equally how these are mitigated with and through the discourse of space and borders. We take a constructionist approach to the 'migrant' problem in the EU and UK where risk is socially constructed through political discourse.
\end{abstract}

\section{Introduction}

Risk analysis has a blind spot. While spatial analysis has figured in the demarcation of risk in terms of environmental degradation, hazards and epidemiological outbreaks, there is a dearth of academic literature on how the border space constantly re-ignites renewed depictions of threat in the guise of the migrant, refugee or the illegitimate 'Other' in the area of risk studies. Many processes and phenomena implicate space as presenting new forms of cartographic reconfiguration as well as new forms of challenges for humanity over time. From colonisation, the emergence of the empire, the formation of new nation-states after World War II to the discourse of globalisation as well as the rise of the internet portending a 'global village', the concept of space has imposed different cartographies on human imagination and in our constructions of local and global risks. Throughout history, there have been counteracting tendencies to unify spaces and equally to uncouple spaces. Imperialism, colonisation, the rise of nationalism post-World War Two (and in tandem the declaration of independence and selfrule), the Cold War, the truncation of Europe into East and West and the breaking of the Berlin 
Wall or the formation of the European Union saw spaces being reclaimed and renamed, unified and splintered.

With a highly-interconnected world, risks, crises and environmental concerns have affected us despite geographical distance. Today when flights go missing or crash, the impact of the loss and implications for security are globally shared. Globalisation with the development of convoluted supply and demand chains disseminates risk in much more intricate and complex ways (Beck 1999). It is no longer possible to draw a line around our geographical boundaries and stay secure within it. Unforeseen new risks ranging from terrorism, cyber-attacks, biochemical warfare to environmental decimation as envisaged through the 'epoch of the anthropocene', where man's interactions with the earth invariably implicates both the drawing down of its resources and creation of new risks, mean space is constantly reconfigured, both in the remodelling of risks as well as in our sociological imagination of space, and equally what is seemingly 'proximate' or 'distant' in a world increasingly connected through new media technologies.

Space is a recurring concept in risk literature but often it takes different paradigms in mitigating risk. A renewed emphasis of space emerged with $9 / 11$ and the attacks on the Twin Towers, which again solidified an ideological divide between East and West in terms of values. The subsequent 'war on terror' by the West saw the rise of an age of anxiety where Western cities became the target of attacks. Against this backdrop, terrorism as a global phenomenon envisaged through exploding cities and crashing planes has made risk a pervasive issue. It reignited the consciousness about space and anxieties about borders being permeable to new forms of risk. While terrorism remains one of the biggest risks for governments and nationstates today, the conflict in the Middle East and Africa and other parts of the world are seemingly creating new threats through the 'migrant' or the refugee/asylum seeker. As terrorism reconfigured our notions of proximity and distance in terms of where attacks can happen, the border space acquired new political significance of being constantly transgressed through forced migration and displacement of peoples, re-invoking the 'governmentality' (Foucault 2007) of modern nation states. The violations by alien bodies are perceived as risk to the social, cultural and economic stability of states and hence the border is invoked and fortified through the wall, fence, razor wire, border patrol and forms of citizenship controls.

Existing risk literature discusses the border space and migration in terms of securitization and terrorism (see Aradau \& Van Munster 2007; Bigo 2014; Walklate \& Mythen 2015), as a risk to ecosystems (see de Sherbinin et al. 2012) and even the association of contamination diseases with foreigners or immigrants (see Prothero 2001; Darlington et al. 2015). Discourses about space have as such reviewed the risks posed to the environment in the age of the anthropocene. In view of this, both migration and climate change are seen as top risks facing the global economy (Yang 2016). Though migration has been framed as generating risk/uncertainty in popular, political and policy discourses, Allan William and Vladmir Balaz (see 2012:167) assert that there is still a dearth of attention on this area in terms of risk literature, particularly a comprehensive theoretical framework of migrant 'Other' as threat in risk literature. They point out that 'migration is both informed by risk and uncertainty, and generates risk and uncertainty, 
whether for migrants, non-migrants in sending communities, or populations in the destination countries' (2012: 167). They contend that migration is also perceived to generate risks for destination societies, linked to a process of highly racialised and ethnicised 'Othering' (2012: 167). As such they argue that while migration research often emphasises the importance of risk there is often very little explicit theorization on the role of risk, revealing no single comprehensive theoretical framework for risk and uncertainty.

This paper, while acknowledging the lack of a comprehensive theory in manufacturing risks about the Other in modernity, approaches the notion of risk and social production of categories with the nation-state through Foucault's notion of governmentality. It takes a constructionist approach in analysing how government discourses construct risks through the so called 'migrant crises' and the violation of the borders, and equally in the techniques it employs to mitigate risk for the UK and in its position within the EU from 2010 till 2016 (pre-Brexit) where spatial references dominate discursive risk construction.

\section{The State, Borders and 'Governmentality'}

Today what could come through your mailbox in the security of your home to what can be left unattended in a public place such as an airport entwines risk and space in complex ways. For Ulrich Beck the nature of risks is historically unprecedented in terms of their temporal and spatial reach. Beck (1986) contends in his book Risk Society, that in the past citizens expected their governments to deliver 'goods' whether this be better living conditions, consumer choices or living wage. In contrast today, citizens expect governments to protect them from the 'bad' ranging from the unknown to environmental and technological risks. In postmodern consciousness, with the advance of science and technology posing new forms of biotechnological hazards from the nuclear age, there is a preoccupation with safety and security and a need to reduce and manage risks actively in society. Joffe (1999), writing from a social psychology perspective, argues that a personal invulnerability to risk is evoked by externalizing the perceived threat, effectively transposing it to others

Despite an overriding discourse of global interconnectivity and reconfiguration of time and space through technologies, the border space has been renewed as a body politic of risk. Who is contained within and without produces social categories bound through legality and illegitimacy (see, Charteris-Black, 2006). These social categories emerging through who we keep in and who we keep out produce risk typologies in coding those who violate borders. The transgression of the border as a boundary marker is seen as a threat to the sovereignty of the nation-states and its ability to safeguard borders. The production of the category of the 'other' is manufactured both through state structures and people's culture of fear of the other i.e. taking away jobs, eating into the benefit system or morphologically not looking like the rest of the population (see Joffe, 1999). The dissolution of territorial boundaries and the flow of the alien other can engender a "fertile breeding ground for the development or intensification of xenophobic politics" (Dillon 1995: 355). 
In drawing on Foucault's theory of 'governmentality', the concept of population as an invention of the science of statistics offered governments a mechanism to specify and organise populations through the complementary modes of power and knowledge to institute a rationalising administration. For Foucault governmentality "subordinates law, custom, force, and ethics into the strategic and tactical' by which the population is ordered and delimited" (Dillon 1995: 329-330). Dillon (1995: 330), in his analytic of Foucault's governmentality, points out that the concept itself does "not rely in law as juridical power but on philosophical and epistemological presuppositions which are institutionalised in knowledge practice through which subjects (and subjectivities) are born". Governmentality as such did not only denote power regime nor its extension to all walks of life but also its 'forceful delimitation of space in which it can operate' (Dillon 1995: 333). As such ordering of populations entailed the configuring of rights and responsibilities, statistical coding of people and their domestication through technologies of government. Hence by-products of such cataloguing in today's biopolitics include the category of the migrant, the refugee and the asylum seeker. Borders have become a key locus for discipline and punishment, in tandem, complex modes of criminality have emerged in the modern nation-state (Bowling 2013) where these forms of criminality can be managed through risk categories and risk discourses.

Risk construction and management in tandem with the rise of the nation state as a form of corporate power in modernity sought to take 'everyday' fears and threats and turn them into rationalist discourses and arenas which could be managed. Collective insecurity and fears of people became part of government's risk management where discourse in public spheres and opinion polls provided a means to elicit public opinion. Invariably, people and their perceptions are intricately entwined in risk management and policy dimensions. The ordinary man as citizen or consumer is incorporated into risk management and policy making by eliciting their responses and converting responses into data which can be managed through elite formation and through 'expert knowledge'. This includes affective and emotional responses to issues. The 'visceral public' as such is constantly mediated through the rationalistic approaches of the expert. If the public construct risk through their lived experiences or false perceptions, the science of risk sought to uncouple the visceral from the issue under scrutiny and to transform much of it into a construct to be managed through the imperative of the policy makers. Part of this imperative is to transpose risk onto the 'Other' (see Joffe, 1999). The phenomenon of Othering and the social production of categories in society can be framed in rationalised discourse in terms of immigration, policy, enhancing border patrol and in social semantics which turn refugees into migrants where they are seen as opportunistic entities adding to the 'politics of depletion' particularly in periods of economic downturn. In view of this, the spatial category of the border and the boundary become both productive and imaginative spaces to encode risk and uncertainty and the governmentality of the nation-state in modernity.

Bosworth and Guild (2008: 703-704) assert that while permeable borders are a defining aspect of modernity due to global capitalism, mass tourism, the communications revolution and evolving forms of regional governance such as the European Union, most industrial, democratized nations have, like the United Kingdom, sought to restrict access to non-citizens. Bosworth and Guild, in evoking Zygmunt Bauman's notion of 'liquid modernity', ascribe it as 
a period of fluid and shifting boundaries, borders and identities, when, just as the barriers to capital, goods and information have eased, the movement of people has been subject to increasing scrutiny and, for the most vulnerable among them, has been all but (legally) curtailed (Bauman 2004; 2007). Asylum seekers and unskilled workers are presented as a drain on public services and a threat to local wages, social cohesion and national culture. Since the Twin Towers attack in 2001 and London Underground bombings in 2005 such fears have become "more diffuse where unconnected migrant groups are linked by a single discourse on border control that spills over into the governance of all non-citizens and beyond" (Bosworth and Guild 2008: 705).

Invariably, the state plays a significant role in risk management in modernity. However, governments are just one actor in this process and, as Foucault argues, power is distributed across society - in the media, in NGOs, and in local community groups amongst others. They all play roles in defining the risks associated with migrants, or in categorising 'risky migrants', and thereby simultaneously defining, producing and depleting these risks. Beck (1986) positions the mass media as playing a crucial role in processes of risk revelation by casting a 'spotlight' on them (see Cottle 1998: 5). As such Beck's conception of the 'relations of definition' premises on how risks can be socially manufactured in public discourses. "Relations of definitions include the rules, institutions and capacities that structure the identification and assessment of risks; they are the legal, epistemological and cultural matrix in which risk politics is conducted" (cf. Cottle 1998: 7). Risk production as such is often iterative. In the case of the 'risky migrant' it veers between the public's culture of fear of the Other to the government's forms of control over populations and their management.

Threats and fears that emerge from the public, and these perceptions which can pose renewed risks to societies through the emergence of conflict or disaffect on the ground, need more scrutiny in terms of whether there is a 'lack' in the risk arena in failing to understand people as anthropological objects and subjects. One main area where such an approach would be invaluable is the issue of immigration where the fear of the other can defy a 'scientific and rationalist' management. The anthropological turn in risk literature is necessary and vital to identify risks which emerge through peoples' constructions of risk or their perceptions of the Other. Human configurations of space and its emotional co-location with both belonging and casting out of the Other become significant elements in both risk communication and policy dimensions with regard to immigration.

\section{The EU, UK and the Border Space}

The notions of space and borders have been recurring themes since the inception of the European Community which preceded the European Union where the overriding imperative has been to facilitate movement and mobility for the mutual benefit of member states. The founding principle articulated in the Treaty of Rome (1957) is the free movement of capital, 
goods, services and persons between member states. It was the economic rationale that persuaded Britain to join the European Community in 1973 amidst a perceived risk that the demise of the Empire lead to a loss of markets and marginalization in a globalising world. From the outset of membership, a strong Eurosceptic tradition of thought hostile to closer ties to Europe has remained (Wall 2012). Federalist inclinations are seen as a threat to British sovereignty particularly in view of a British identity rooted in the notion of the 'spatial separation of an island, psychologically distant from the European integration movement' and of a historical and racial distinctiveness (Daddow 2013:212-213).

This Euroscepticism and perception of being exceptional was given added impetus when the Maastricht Treaty (1991) turned the Community into a Union (i.e. from a predominantly trading block to a more political entity with looser internal borders). In the same year, France and the UK reached an agreement to place juxtaposed controls, ${ }^{1}$ i.e. immigration checks, at designated cross Channel sites, including at Coquelles near Calais. These controls mean checks take place before boarding a train or ferry rather than on arrival. In 1994, the Channel Tunnel linking Britain to the continent opened and a year later the Schengen Agreement was signed allowing for the removal of internal borders between signatory states with the purpose of further facilitating the efficient movement of people, etc. Britain opted out of Schengen, choosing to retain entry and exit controls of its own borders, on the grounds that it wanted to cede neither sovereignty nor security to another entity. Thus, the external border to Schengen and Britain's border with the continent became Europe's seaboard with the Channel.

In 1999 the agency Frontex was created to advise and support those countries whose own borders formed the external boundaries for the EU as a whole. In tandem, the 'Risk Analysis' unit was established to capture and interpret data on global trends that affect border security including cross-border crimes such as human trafficking and irregular migration (Frontext u.d.). However, the border of the EU has not been rigid, shifting outwards through six waves of enlargement. In 1973, it moved westward with the inclusion of the UK and Ireland, in the 1980s it pushed southward to the Mediterranean to Greece, in the 1990s northward to encompass some of Scandinavia and eastward after the new millennium to include Hungary and Croatia, bringing the total number of member states to 28. Membership also brought access to new markets and to mobility of labour.

Two major migration narratives have dominated British public debate since the 1990s; loss of control over borders and the economic threat of migration through expansion of membership. Enlargement to include the Polish in 2004 and the Bulgarians and Romanians in 2007 were

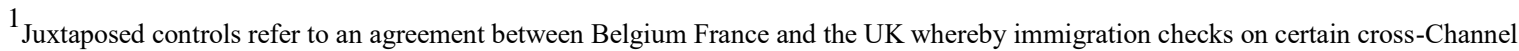
places take place before boarding a train or ferry rather than on arrival after disembarking. The 1991 Sangatte Protocol between France and UK provided for border checkpoints to be set up by France in Cheriton, Kent, and by the UK at Coquelles in France. Juxtaposed controls mean that when travelling from France via Eurotunnel, travellers have to clear both French exit checks and UK immigration and customs checks in Coquelles before boarding the train. Juxtaposed controls for Eurostar and ferry only consist of immigration pre-embarkation checks, while juxtaposed controls for Eurotunnel consist of both immigration and customs pre-embarkation checks. When travelling from the UK to Belgium or France by Eurostar, immigration entry checks into the Schengen Area take place before boarding the train in the UK rather than when arriving; carried out in UK stations before embarkation by French Border Police which also checks those passengers travelling to Belgium. When travelling from Belgium or France to the UK by Eurostar, passengers clear immigration exit checks from the Schengen Area as well as UK immigration entry checks before boarding the train.
} 
accompanied by media scare stories warning of an impending 'invasion' (Ibrahim \& Howarth 2016a; Light \& Young 2009; Ibrahim \& Howarth 2016b) as well as questions about the notion of 'Europe' and about who has the right to speak about 'what Europe is and should be' (Feakins $\&$ Białasiewicz 2006: 658). Public, media and some political perceptions have centred on the economic threats of what are seen to be 'waves' of Eastern European 'migrants' coming to take 'our' jobs and act as a drain on services including health and education (see Dennison \& Goodwin 2015), igniting deep-seated fears about the loss of sovereignty and identity (DarianSmith 1999; Sellar et al. 2009).

In addition, the UK's border politics have been shaped by irregular migration. Post-World War Two international agreements sought to protect civilians fleeing persecution by defining who is a refugee and therefore entitled to seek sanctuary and avoid penalties for illegal entry in search of this. In Europe, dominant discourses of rights were disrupted, first, by the political upheaval that followed the break-up of the Soviet Union, the Eastern bloc and the former Yugoslavia in the 1990s. The massive displacement that ensued from the geopolitical conflict was accompanied by a shift particularly in Europe in the dominant discourse away from rights, protection and sanctuary to one of the threats posed by 'unregulated, unaccountable population shifts' to the political stability and cohesion of the states (Bosworth 2008a: 201; Dillon 1995).

From the late 1990s there has also been growing concern about people trafficking and smuggling and, after 9/11, about the possibility of terrorists infiltrating the asylum seekermigrant routes. Internationally, there has been a shift from the discourses of protection and rights to discourses of threat and risk depending on the perceived scale of migration and on whether the migrant is labelled a refugee, trafficker or terrorist (Howarth \& Ibrahim 2012). The privileging of security and border control in policy responses to migration is a retreat from discourses of according protection and rights to refugees which emerged after the Second World War in international agreements on how civilians should be treated in conflict; particularly the right to seek sanctuary, to claim asylum and avoid penalties for illegal entry in search of these (see Fekete 2005).

The massive flows of irregular migration in the EU following the Balkans conflagration in the late 1990s were a precursor of what was to come two decades later. Political instability around the world escalated such that in 2014 the UN High Commissioner for Refugees warned that world was facing its biggest 'forced migration crisis' since the Second World War (Gower \& Smith 2015). Millions of people, half of whom were children, had been uprooted by conflict or persecution, stranded on the edges of society as long-term internally displaced or as refugees. The scale of displacement has required more co-ordination between states than before (UNHCR 2015b; UNHCR 2015a; Ibrahim \& Howarth 2015). Ongoing instability across its borders with the Middle East and North Africa as well as Sub-Saharan Africa and Afghanistan have contributed to Europe's 'migrant crisis' reaching a crescendo in 2015. The crisis had been building since the 'Arab Spring' in 2011, but in 2015 Frontex estimated that twice as many asylum seekers and migrants $(859,000$ people) had arrived on Greek and Italian shores in the first 11 months of the year than in the previous five years combined, culminating to 4,000 arrivals a day at one point in the Greek islands with 3695 dead or missing while crossing the Mediterranean in 2015 (cited in Papademetriou, 2015). 
Frontex has identified three main routes into the EU. The Central Mediterranean route (Italy and Malta) is the most dangerous route with most travelling on smugglers' boats from Libya, Tunisia and Egypt (Banulescu-Bogdan \& Fratzke 2015). The second route is the Eastern Mediterranean Route (Greece/Aegean Sea) which became the primary maritime route in 2015 with in excess of 350,000 crossing from Turkey to Greece (mainly to Lesbos and Kos near the Turkish coast). The third route is through the Western Balkans where more than 155,000 have crossed from Serbia into Hungary.

As the 'sense of chaos' at Europe's borders escalated, the migration and humanitarian crisis 'tested' European consensus and governance, creating a 'crisis of solidarity' as internal divisions deepened within the EU over who was responsible for dealing with the need (Papademetriou 2015). The unprecedented scale of the current migrant crisis and the initially slow, ad hoc response from EU member states has posed an 'existential crisis' for European institutions and Schengen (Papademetriou 2015). The scale of the crisis had 're-ignited deep internal divisions' between the traditional 'frontline' states such as Greece and Italy as well as new 'frontline' states which had emerged in transit countries such as Croatia and Hungary (Banulescu-Bogdan \& Fratzke 2015).

While Britain has contributed to the militarization of the EU's external borders e.g. by providing ships in the Mediterranean, the political pre-occupation has been with the movement of migrants and refugees into Calais where the country's external borders lie. The 20-mile stretch between Calais and Dover is the narrowest point in the English Channel between Great Britain and the European mainland. Calais-Dover has practical significance as a major route in and out of Britain for people and goods (Readman 2014). With the opening of the Channel Tunnel in 1994 Calais became the major transit hub with migrants congregating there in the hope that they could hide on trucks heading across to Britain and so breakthrough border controls. The imposing of juxtaposed controls has made it harder to move on so Calais is thus variously represented as a 'bottleneck, barrier, border and breakthrough point' (Oxford Migration Observatory 2014).

In terms of EU migration and asylum policies, Britain was neither "wholly in or wholly out", signing up to a little over half of the measures introduced by the EU such that engagement was "conditional and differential" (Geddes 2005: 732) with a particular emphasis on security and border controls at the external frontiers of Britain. In July 2002, UK and France agreed to close Sangatte refugee camp because it was seen as attracting migrants and a source of conflict between groups of them. After the closure of Sangatte, asylum seekers and migrants in Calais became relatively low profile. However, growing numbers fleeing Iraq, Somalia and Afghanistan set up informal camps known as 'the jungle' which attracted media attention in 2009 , as did the demolition of the camps. The Calais crisis came back into media scrutiny due to bigger events in the Mediterranean, where unprecedented numbers of refugees were risking their lives in overcrowded and rickety boats. On 2 September 2015 the tragic image of Aylan Kurdi dead on the beach ignited further interest in the Calais crisis, which saw a surge in photo coverage of both the Mediterranean and Calais crisis. Hence the forced migration in Syria and parts of Africa converged with anxieties about opening up the UK to new members such as Romania and Bulgaria between 2010 and 2016. 


\section{Methodology: Why the Constructionist Approach?}

Having set out the context of the so-called 'migrant crises' in the UK between 2010-2016 (i.e. since the advent of a Conservative-led government), we move on to outline how the political speeches and announcements are part of the elite formations responsible for the complementary power/knowledge binary which form the basis of governmentality of nation-states in modernity. In assessing the construction of risk through political discourses about migrants in the UK we take a constructionist approach. Tulloch and Lupton (2003: 1) contend that risk knowledge can be historical and locally mediated and tend to be constantly contested and often a subject of dispute. The SARF model (or the Social Amplification of Risk Model) of Kasperson et al. (1988) contends that social and institutional actors, factors and contexts amplify or attenuate risk messages as they pass through society, ultimately influencing risk perception. Although SARF has mainly been used to analyse health, environmental and food risks it is highly malleable and able to be adapted to any type of risk (see Pidgeon et al. 2003). The proponents of SARF argue it is not a model per se but a broad framework capable of accommodating realist or constructionist approaches, the latter of which contends that risks exist in knowledge as social constructs which emerge through the collective generation of meaning through discourse (Schwandt 1994: 127). Constructionist approaches assume risk or risk discourses are endemic in late modernity. Furthermore, a risk is not only a response to objective reality but is transformed and mediated through processes of communication (see Douglas \& Wildavsky 1983) or is socially constructed, brought into being and managed as part of social power (see Beck 1986). Sociological-constructionist approaches, in particular Irwin's soft constructionism, do not deny the reality of problems but argue that 'both real and imaginary ... [ones] need to be socially constructed if they are to find a place on the ... [political] agenda' (Irwin 2001: 21-22). In essence a constructionist approach enables links to be made between discourse and perceptions as well as the social and institutional context in which risks may be constructed and managed.

As such we undertook a discourse analysis of the government statements, speeches and debates to delineate the social construction of risk at the border and equally its mitigation. In employing a constructionist approach we sought to discern the dominant discourses, mainly through patterns whether these be repetitions or the use of selective salient terminologies (i.e. such as 'exceptionalism') to encode their ideological and social constructions of what might constitute risk. The discourse analysis as such was mined by identifying recurring themes of threats and equally discursive justifications to ward off these threats particularly in asserting the national sovereignty within Fortress Europe. The themes were then read and re-read to discern their link to context i.e. how context shaped discourse and how discourse shaped context. The discourse analysis that followed revealed both the rhetorical construction of the border space and its incumbent threats and at a metal-level it showcased the ideological negotiation of risks in rhetoric and statements.

We analysed the construction of the 'migrant' as risk in political discourses between 2010 and 2016, particularly in the context of the migrant/refugee camps in Calais and the increased 
forced migration in the Mediterranean. It needs to be pointed out here that while the terms 'migrant' and 'refugee' were political and legally separate and distinct, the recurring references to both these terms tended to conflate them as one entity in many of announcements and speeches particularly with reference to Calais where it was deemed as more difficult to delineate the refugee from the opportunistic migrant. By 2015 and 2016 discourses of refugees while dominant with Cameron and May, were mainly in reference to the crises in the Mediterranean. It is notable that the term refugee remained reserved in British political discourse for Syrians in camps outside the EU (see Cameron, 2012, 2015b, 2016b; Cameron \& Orban, 2016; May, 2012). Discourses of 'migrant' or 'illegal migrant' were reserved for other nationalities i.e. Eritreans, Somalians, Iraqis and Afghans and those who had transgressed the borders and were moving across Europe illegally. However, in the Mediterranean and Calais the two terms coalesced and enactments pointed to the difficulties in identifying refugees from the migrant or in tracing their origins of migration. UNHCR has repeatedly contested this spatial and ethnic delineation of refugee and migrant in British political discourses repeatedly arguing that the overwhelming majority of those crossing the Mediterranean were fleeing conflict and persecution and should in tandem be considered refugees. British political discourse continued to use the term 'migrant' to refer to those in Calais and the generic 'people' for those crossing the Mediterranean. The lack of delineation between migrant and refugee became a deliberate discursive device in coding the bodies as a form of risk and as suspect entities.

We mined 261 announcements (i.e. press releases, speeches and statements) between 2010 and June 2016 from the gov.uk website. Relevant items were identified by selecting the 'immigration and border' policy area on the website and 'all departments'. A subsequent search was done on 'refugee OR migrant OR Calais OR Mediterranean' (see table 1 for a distribution of documents over time). A narrower search was undertaken on 'Calais' and on the 'Mediterranean', the two spaces of crisis that our preliminary readings suggested British politicians had been primarily concerned with. We did a preliminary analysis of the emphasis in the headlines of announcements to obtain an overview of possible recurring discourses and shifts (or continuities) over time and what emerged were two distinctive periods. The pre-crisis period between 2010 and 2014 had fewer announcements (see table 1), most of those that were made were by junior ministers or anonymised departments (Green, 2010; Home Office, 2010a; Home Office and Border Force, 2013) and tended to focus on individual 'stowaways' apprehended before they could breach Britain's controls. These often conveyed a sense of rational and effective management of the borders. As such, discourses between 2010 and 2014 were dominated by relatively routine border management matters where risk was constructed as implicit or latent and the body of the migrant/refugee as contained and containable.

\begin{tabular}{|l|l|l|l|l|l|l|l|l|}
\hline \multicolumn{2}{|l|}{ Table 1: Government announcements on immigration and borders } \\
\hline & ${ }^{*} 2010$ & 2011 & 2012 & 2013 & 2014 & 2015 & ${ }^{2} 2016$ & TOTAL \\
\hline CALAIS & 7 & 2 & 0 & 3 & 2 & 6 & 4 & 24 \\
\hline MEDITERRANEAN & 2 & 0 & 0 & 0 & 1 & 20 & 13 & 36 \\
\hline $\begin{array}{l}\text { REFUGEES OR MIGRANTS } \\
\text { OR CALAIS OR } \\
\text { MEDITERRANEAN }\end{array}$ & 39 & 35 & 23 & 44 & 37 & 49 & 34 & 261 \\
\hline
\end{tabular}


* 2010 is a truncated year from May to December because of the general election and 2016 is truncated from January to June because of the timing of this research.

However, between 2015 and 2016 there was marked changes both in the quantitative and qualitative intensification in discourses about borders and risky bodies (see Table 1) and in the greater prominence of Prime Minister David Cameron and Home Secretary in shaping British political discourse on the migration/refugee crisis. There was also more emphasis on intergovernmental engagement, bilateral talks and militarization, a reflection of the Europe-wide crisis. Furthermore, the constructions of the migrant/refugee body shift from the individual to the collective where the weight of numbers exerting pressure on the borders is presented as posing a risk of multiple breaches on the British border in Calais and on the EU border. The perceived expansion of risk was accompanied by a widening of collaboration beyond the historic British-French ones over Calais to the inter-governmental ones with heads of state on the borders of the EU, both inside and outside. That is, the perception as to the ability to contain the crisis on Britain's borders in Calais was constructed as contingent on addressing the flows of migrants/refugees from beyond the EU. In view of the intensification of discourses about the borders and risk between 2015 and 2016, we augmented the data with a search on Hansard on David Cameron/Theresa May, the two main government figures involved in the crises in addition to the original search terms of 'refugee OR migrant OR Calais OR Mediterranean'. This elicited 13 relevant debates in 2015 and 8 in the first half of 2016.

The period between 2015-2016 as such yielded more discourses compared to 2010-2014 comprising the pre-crisis period. The two periods provided a contrast between periods of routine border management as opposed to periods of crisis. The pre-crisis years also contained constructions of latent risk that presaged what was to come. Prior to 2012, the term 'refugee' was rarely used in connection with Europe and mainly by junior ministers in connection with asylum seekers (see Green, 2011). Statements in 2012 by Cameron and May marked the beginning of a shift (Cameron, 2012; May, 2012). In 2014, the government under public and media pressure for not doing enough to address the growing humanitarian crisis, launched a programme aimed at taking 'vulnerable' Syrian 'refugees' from UN camps in North Africa (Brokenshire, 2014) and in 2015, within weeks after the image of Aylan Kurdi went viral the Ministerial Committee for Syrian Refugees was set up and special post of Minister for Syrian Refugees was created in the Home Office (Cameron \& May, 2015). The purpose of analysing political discourses of 'migrants' over six years and in particular its intensification between 2015 and 2016 was to derive an overview of discourses of risk as emanating from outside the EU. The main discourses which we identify in our analysis as such emerge from the data mined in this crucial crisis period between 2015 and 2016.

Our analysis focused on how the border space ignites renewed forms of threat in the guise of the migrant. Recurring themes emerged in the readings and against the political and economic contextualisation of the EU and the UK. The dominant discourses included the border as a space of infiltration, breaches of patrol and of security or militarization. Equally these themes interwove other related discourses including ascribing criminality to the migrant and threats to our sense of nationhood, often mitigated through the notion of exceptionalism. Our review of political rhetoric on risk and migration into the EU situates migration as posing multi-faceted 
and interweaving risks, as such the resonant themes and the utilisation of distinct discourses were not stand alone categories and were often inter-related. The announcements and elite political discourses were analysed against the political context of the EU and UK where the expanding space of the EU is counter-imagined against the bounded nation-state of UK.

\section{Analysis and Discussion}

Our analysis of government discourses and announcements revealed that the issues of borders enacted constructions of risk at different levels particularly ensconced through the cartography of the EU, juxtaposed against the nation space of the UK. Hence, the risk construction and mitigation were dialectical; on the one hand, risk was constructed through the migrant issue and equally the government would offer mitigation to the risk to rationalise it through policies, securitization and militarization initiatives and through statistical measures, as well as underscoring how they departed from the majority of EU member states and hence were ahead of the game.

The key shift between pre-crisis (2010 and 2014) and crisis periods (2015 and 2016) was in the more prominent role played by Cameron and May in shaping British political discourse on the migration/refugee crisis. Furthermore, the constructions of the migrant/refugee body shift from the individual to the collective where the weight of numbers exerting pressure on the borders is presented as posing a risk of multiple breaches on the British border in Calais and on the EU border. The perceived expansion of risk was accompanied by a widening of collaboration beyond the historic British-French ones over Calais to the inter-governmental ones with heads of state on the borders of the EU, both inside and outside. The main discourses emerging from the analysis are as below;

\section{Notion of Exceptionalism}

While the expansion of the borders of the EU is seen as a threat, the mitigation of the risk was often presented as the UK being in a position to carve out a position of 'exceptionalism'. Britain's membership of the EU had conferred on its citizens the right to 'travel freely' but it also conferred a reciprocal right on those of and in other member states to do likewise. One of the most contentious and emotive issues during the Brexit referendum debates was whether the price paid for Britons' freedom of movement had been a loss of control over immigration, posing a threat to its sovereignty, hence the slogan 'take back control of our borders' which became part of the discourse of Brexit supporters (Somerville 2016; O'Connor \& Vina 2016). The 'Remain' camp cited the stance of exceptionalism as providing the means to exert a degree of control over the borders within the EU union (i.e. the ability of British citizens to travel freely while the government retained the mechanisms to control entry of EU and non-EU citizens through border checks).

David Cameron and Theresa May, both of whom positioned themselves within the 'Remain' camp, employed this rhetoric of 'exceptionalism' and the exercising of sovereignty particularly 
in relation to the British opt-out from the Schengen agreement ${ }^{2}$ and its retaining of border controls when others had "taken theirs down" (Cameron 2015e). The retention of the right to deny entry and the exercising of responsibility in retaining checkpoints were key technologies of control in maintaining 'hard borders' (Cameron 2016b). British political discourses presented the signatories of Schengen as having forfeited these controls and as a consequence were struggling to manage an unprecedented movement of people as 1 million refugees and displaced persons crossed the Mediterranean in 2015, a four-fold increase on the year before (UNHCR 2016). Movement on this scale was seen as having exposed the vulnerabilities created by Schengen and some, for instance Germany, had been forced to resort to extreme measures of temporarily closing their borders in a bid to reassert sovereign control over moving bodies and mitigate the risk overwhelming numbers posed to the polity. British exceptionalism in opting out of Schengen could therefore be presented as rational in itself as well as facilitating the rational administration of risk. Exceptionalism allied to the 'natural advantages' of being an island meant that the UK was 'less directly affected' than other European countries by the refugee crisis (Cameron 2015h). In contrast, as the crisis mounted the Schengen countries were seen as belatedly mounting a rear-guard action and trying to put in place 'a pale imitation of what we already have' (Cameron 2016a).

The 2015 migration crisis, in British political discourse, had drawn attention to a critical faultline encapsulated in Schengen. In removing internal borders, the Schengen nations had become dependent on the effective management of external borders by the EU's 'frontline' states and Frontex. However, Cameron presented the external borders of Fortress Europe as permeable and the management of them irresolute. The rhetoric of Britain's 'hard' borders stood in contrast to the EU's 'soft' ones on the Mediterranean and tougher measures in Calais against the need for the EU to "prove" that it has an external border (Cameron 2015c). The tightening of British-French juxtaposed controls at Coquelles was contrasted with the need for a "more determined' response elsewhere in Europe. The forfeiting of the techniques of control with Schengen and the absence of a decisive alternative meant that some member states had themselves become a risk entity and the freedom of movement across the EU necessitated a tougher stance in the management of Britain's external borders in Calais. Border controls became symptomatic of Britain's differentiated and conditional approach. Well managed controls were presented as one of the key mechanisms for letting 'legitimate' people and goods to pass through while 'reducing threats' of illegal immigration, smuggling and terrorism through Britain's second line of defence at its 'frontline' in Calais (May 2011; May 2015a).

Government discourses also sought to portray the UK as being ahead of the issues in facing $21^{\text {st }}$ century forced migration. Although Cameron distanced himself from "responsibility" for the management of the EU's external borders, he was willing to dispatch British experts and border technologies to Europe's "hotspots" while continuing to make the government priority "properly" policing its own external border at Calais (Cameron 2015c). The retention of the

\footnotetext{
${ }^{2}$ The Schengen agreement allows for states to temporarily re-introduce border controls, but generally this has been used in the aftermath of a terrorist attack and 2015-6 was the first time this had been done in response to irregular migration. The first to do so were Germany and Austria in September 2015, followed by Denmark, Norway and Sweden for between 4-8 months. Belgium, Hungary and Slovenia did so for shorter periods.
} 
technologies of government in the form of off-shore border controls in France meant Britain was better equipped to detect and deter moving bodies that posed a risk before they landed in Britain. The rhetoric of juxtaposed controls ${ }^{3}$ at Calais and investment in tighter security there as well as the use of the latest technologies intended to detect moving bodies served to underscore a resolute response to shoring up Britain's external defences (Cameron 2015h). In frequently asserting that Britain's external border lay in Calais and not with the Schengen states on the Mediterranean, Cameron not only differentiated the limits of his responsibility but also distanced his government from the apparent failures and loss of control on the EU's external border. More was needed from the EU to "regain control" of its external borders and "contain migration flows" (Home Office, 2016). The need to retain or reassert control of the borders was a recurrent narrative in our analysis but often it was denoted through Europe's inability to contain it in a more concerted manner.

\section{Transference of Risk and Responsibility to the Migrant Body}

As the deaths from drowning in the Mediterranean mounted, ministers faced a conundrum. They risked compromising Britain's reputation as a humanitarian nation if the government held to its policy of refusing entry to refugees already in the EU. Or if they accepted the European Commission's proposal of a quota they risked diluting their policy on "hard" borders and, to Cameron's mind, legitimizing illegal methods of entry and breaches of controls. Discursively, the government managed the conflicting discourses by transferring risk and responsibility to the migrant body while seeming sympathetic about the tragedies unfolding in the Mediterranean. On the one hand, the migrant body was presented as desperate, preyed upon by those intent on profiteering from a "vile trade in human beings" (May 2015c) yet deluded in buying "false promises" by people traffickers who then loaded migrants "dangerous vessels ... sending them - in many cases - to their deaths" (May 2015a). On the other hand, government rhetoric constructed the migrant body as complicit in its own risk, colluding with smugglers in cross-border crime, reckless and irresponsible in choosing to "risk their lives" and those of their families in making the treacherous journey to Europe (May 2015b). Responsibility for the "huge" risks taken and the consequences thereof were transferred to the migrant body rather than the British body politic.

In these circumstances, according to Cameron and May, the response of a moral government was not to legitimize such actions by accepting refugees from among those that had already made the treacherous journey. Nor would ministers incentivize further risks to the migrant body by others who might seek to cross or those that profit from the trade in human traffic (May 2015b). Instead, they set out a strategy which they claimed meant Britain would act rationally and affectively, with its "head" and its "heart" providing help for those in need while working "long term solutions" to the crisis (Cameron 2015h; Cameron 2015f). One manifestation of the strategy was the deployment of Royal Navy vessels to the Mediterranean as part of a humanitarian "search and rescue" for bodies at risk but also to "bust the business model of the

\footnotetext{
${ }^{3}$ Juxtaposed controls are where French exit and British entry checks take place before a person boards a train or ferry at Coquelles at the port of Calais rather than when disembarking in London (Cameron 2015d). This was seen as "a good thing for our country" (Cameron 2015d)
} 
smugglers" and "break the link between getting in a boat and getting settlement in Europe" (Cameron 2016c). The humanitarian and security discourses rather than antithetical became mutually reinforcing around the rational and affective management of the risky body.

The risky body was not only those that put their own lives and those of their families in danger, but also those that set out to endanger European lives. Speculation circulated in the media and parliament, particularly at the time of the Paris and Brussels attacks, that ISIS fighters may have infiltrated the refugee trails and already entered Europe. Offering refuge in Britain to those already in the EU presented a risk of its hospitality being abused if potential terrorists were allowed into the country, while agreeing to take 20,000 Syrian refugees vetted by the UN and the Home Office in the UN camps around Syria could be presented as Britain's compassionate response to the humanitarian crisis and a rational one that safeguarded security. The double screening of refugees in the camps of Lebanon, Jordan and Turkey meant tougher controls to weed out the deviant migrants. It was also a technique of control and mitigation by cataloguing those who could be reclassified as refugees and demarcating others as 'bogus asylum seekers' or with potential links to terrorist groups. The need for additional screening even before they got to Fortress Europe was underscored by the Paris attacks yet also cast the 'migrant' as a suspect category until it had been determined that they were "genuinely fleeing persecution" and this being affirmed prior to entry meant they would not "pose a risk to our country" (Cameron 2015e).

While pursuing a hard line against the refugee crisis in advocating relief from a distance and in refusing to accept its quota of refugees, the government sought to protect its public image on the global stage and invoking its historic image of providing refuge to those fleeing persecution. The government claimed it was upholding the tradition and moral responsibility to help refugees as "we have done throughout our history" (Cameron 2015f) by offering sanctuary to those who had been driven from their homes and taken refuge in neighbouring states (Cameron 2015a). In contrast, the difficulty of vetting and differentiating the 'genuine' refugee from the illegal migrant and the potential terrorist amongst those already in the EU meant knowledge of them was incomplete and all were cast as suspect, particularly at the juxtaposed controls in Calais where British exceptionalism empowered the government to exercise "full control" over who enters the UK (Cameron 2016a). Such controls were presented as non-discriminatory in so far as they applied "to all including EU citizens" (Cameron 2016a). The migrant risk was also often mitigated through statistical data by revealing how many people had been refused entry cited as evidence of rational and orderly control of population movements. For instance, Cameron claimed that since 2010, Britain had "refused entry" to 95,000 people of whom 6,000 were EU nationals and more than half were stopped at juxtaposed borders in Calais primarily because of "national security concerns" (HC 2015b).

The sensitivity of accusations that Britain was retreating from its humanitarian traditions, the proximity of the refugee/migrant crisis in Calais and the Mediterranean and the constant threats to the violation of the borders, prompted the UK to adopt the strategy of relief at a distance. Yet by constructing it in terms of deployment at 'source' the government could construct their endeavours as proactive and rational, addressing both humanitarian and security imperatives. 
While other EU states were distracted by refugee quotas inside the EU, Britain was constructed as getting to the roots of the problem by supporting a "properly functioning government in Libya" that could tackle people trafficking (Cameron 2015f). Accused of not doing enough to shelter refugees, the government reasserted its shouldering 'moral responsibility' by contributing $£ 900$ million, more than any other EU state to humanitarian aid that would enable refugees survive in the countries around Syria (Cameron 2015f; Cameron 2015a). Military assistance was also given to Lebanon and Jordan in the form of the training of soldiers and the building of watchtowers on the borders with Syria (Cameron 2015g) capable of monitoring the movement of large numbers of people, troops or civilians. The interweaving of the migrant and terrorism discourses of risk graphically captured in the aftermath of the Paris attacks can be traced back to Britain's stance in North Africa. The provision of 'massive aid' was not only a moral act of humanitarianism in Cameron's discourses, it was also presented as serving minimize the "numbers making the perilous journey to Europe" (Cameron 2015f; Cameron 2015a) so eased the pressure on borders.

\section{Ascribing criminality to the migrant}

Ascribing of criminality to the migrant, particularly those already in the EU, was a critical discursive technique in legitimizing the fortification of defences at Calais and in transferring risk and responsibility to the migrant body. As the scale of the crisis magnified, discourse shifted from the individual 'stowaway' detected by border police so presented as 'evidence' of the effectiveness of controls to the metaphoric and Cameron's de-humanizing 'swarm' or 'marauders' captured in Foreign Secretary Philip Hammond's interview with journalists (Legrain 2015; Mortimer 2015). While the displaced person in the UN camps outside the EU could be categorized a 'refugee' and those risking their lives crossing the Mediterranean 'migrants' or 'people' colluding with smugglers out of desperation, by the time they reached Calais they were presented as intent on criminal entry into Britain. Their actions were presented as aggressive, a violation of the nation space or concealing movement for the purposes of deception so suggesting a subversion of the legal and hence highlighting the threat to the UK. Constructing developments in Calais in these terms conjured up associations of waves of barbarian raiders having breached the outer defences of Europe and threatening Britain's second line of defence in Calais (Cameron 2015b). Breaches of the defences were captured in accounts of migrants walking along railway tracks, disruptions to trains and infiltrating of lorries. These recurrent references conveyed the sense of constant pressure on and transgressions of the borders. While the refugees and displaced in the UN camps were not assumed to be criminal, the migrants in Calais were and the risk they posed to UK's internal security also became associated with international developments and terrorism into a more amorphous and ever widening sense of danger. The 'threats to our security' had 'grown enormously' ranging from Russia's invasion of the Ukraine on the eastern border of the EU to the emergence of ISIL and the migration flows triggered by the war in Syria. (Cameron 2015h). What emerged was a sense of the EU under siege on two fronts and the Paris attacks 
materialized what might otherwise have seemed to be a distant threat, demonstrating a "direct and growing threat to our country" (Cameron 2015a).

Besides criminality and threat of terrorism, the migrant was also presented as opportunistic and a disruptive force to the economy. The port workers strike had led to the temporary closure of the port and "unacceptable disruption" of traffic and trade (Cameron 2015b). The more pressing concern for the Cameron government was opportunistic migrants taking advantage of the disruption to breach the perimeter fences. Lorry drivers, tourists and local residents in South East England were seen as particularly vulnerable to 'clandestines' seeking to sneak into the vehicles. The British government again presented itself as acting responsibly and morally to mitigate the risk to legitimate traffic posed by migrants by fortifying its borders constantly. The nature and scale of the threat, the trespassing onto rail property and the disruption to legitimate traffic and trade served to legitimize measures more commonly associated with national security. The 'NATO fence't usually used to protect world leaders at summits from terrorist attacks was for the first time in history deployed outside UK and erected in Calais to 'protect' train platforms from migrants (Cameron 2014). Further securitization and militarization of the border controls sought to mitigate the risks presented by this influx of migrants and to create "secure" spaces in which UK-bound lorries and cars within the port could be insulated from "clandestine" activities (May 2015c). Freight vehicles were subjected to "intensified screening" using the "best techniques and technologies in the world" (May 2015a) intended to detect hidden bodies, otherwise invisible to the naked eye. The detailed descriptions and lists of border technologies deployed to detect and deter served to materialize what the government meant by controls: "hard" had become synonymous with militarization and securitization. Statistics were used to capture the supposed effectiveness of these measures (Cameron, 2016a). Between 21 June and 11 July, 11000 attempts were 'successfully intercepted at juxtaposed ports' in France.

Beyond the securitization of the borders in Calais, the Mediterranean coast line became part of Britain's militarized response to the migration crisis (May 2015d). Two Royal Navy ships were deployed to assist Frontex's Operation Triton search and rescue operations and Border Force cutters, which had a long history of "patrolling and protecting our shores" that stretched back centuries (May 2014) were deployed to the Mediterranean to intercept smuggling. The government, along with those from France and Lithuania, used its position on the Security Council to secure UN authorisation for the EU or individual countries to seize the boats of smugglers with the purpose of saving lives or of victims of trafficking (HC 2015a; Cendrowicz 2015). In October 2015 naval operations entered a 'new phase' of boarding ships and arresting

\footnotetext{
${ }^{4}$ The formal name of the 'NATO fence' is the National Barrier Asset (NBA), a collection of temporary security barriers established in 2004 to provide police with the ability "to protect high profile locations or temporary events ... from vehicle borne suicide attempts'. It has been used for NATO summits and the London Olympics but this was the first time the $9 \mathrm{ft}$ high fence has been used outside the UK. It is owned by the government and transported around the UK whose identity is not revealed for security reasons. It has been designed so it can be assembled and transported easily but able to withstand the impact of 7.5 tonne vehicle travelling at $50 \mathrm{mph}$ (BBC Magazine 2015).

${ }^{5}$ Critics labelled the more aggressive policy approach "gunboat diplomacy", NGOs argued it would do nothing to stop the crisis and African states on the Security Council expressed concerns about its inclusion under Chapter 7 of the UN Charter which means it can be militarily enforced. The resolution authorizes the search
} 
smugglers. Thus as the migrant crisis escalated so too did the militarization of the external borders of the EU

\section{Conclusion}

The 'Other' as risk is an under-explored phenomenon in risk literature. How we manage cultural and spatial encroachments by the migrant 'Other' through policy frames and rationalist discourses is the primary focus of this paper. We analysed the 'migrant' as risk in political discourse through a constructionist approach between 2010 and 2016, particularly in the context of the migrant/refugee camps in Calais and the increased forced migration in the Mediterranean. Despite global interconnectivity and reconfiguration of time and space through technologies, the border space has been renewed as a body politic of risk. The phenomenon of 'Othering' and the social production of categories in society is both ideological and political, retaining the migrant body as a sustained a site of anxiety and fear. Foucault's notion of 'governmentality' provides a means to order our fears and anxieties about cultural and spatial encroachments through rationalised risk discourses in terms of immigration policy or effective border control. In view of this, the spatial category of the border and the boundary become both productive and imaginative spaces to encode risk and uncertainty and the 'governmentality' of the nation-state in modernity. The recurrent anxiety over the migrant and the need to contain her in government discourses reiterate the migrant as a pregnant risk body from her transgression of our borders to her depletion of our economic resources. As such the ambit of risk management provides a means to bolster a sense of control over our borders and to equally couch our fears of the Other through a pseudo rationality, a product and condition of modernity.

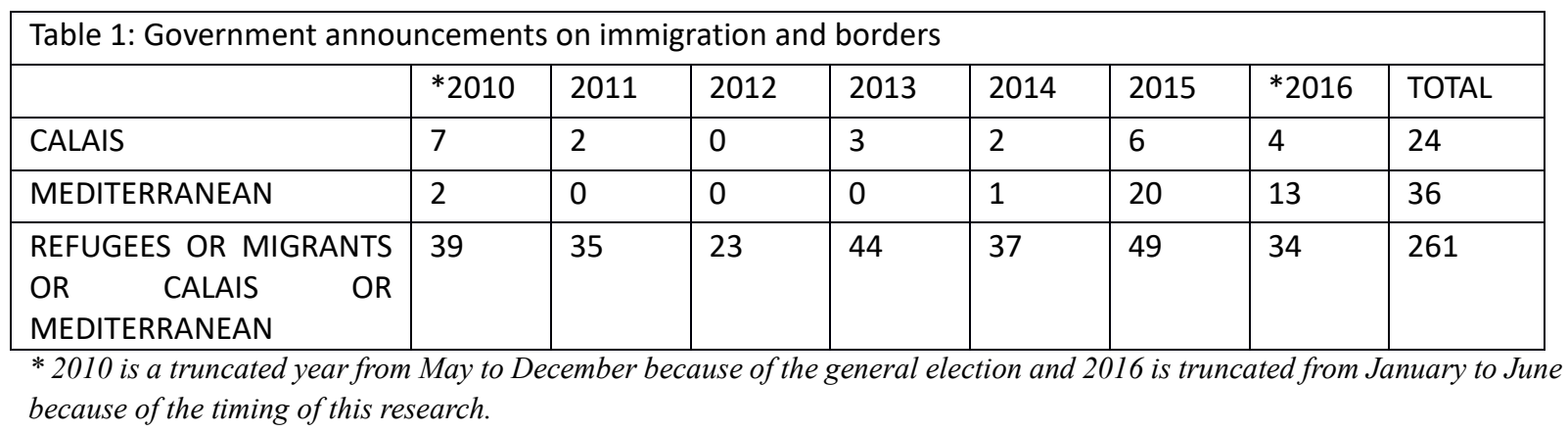

and seizure operation for one year but stopped short of authorizing the destruction of the boats as proposed in the draft resolution (Cendrowicz 2015; Anna 2015). 
Anna, C. (2015). UN OKs resolution to seize migrant-smuggling boats off Libya for a year.CTV News.

http://www.ctvnews.ca/world/un-oks-resolution-to-seize-migrant-smuggling-boats-off-libyafor-a-year-1.2603001. Accessed 10 September 2016.

Aradau, C. \& Van Munster, R.. (2007). Governing Terrorism Through Risk: Taking Precautions, (un)Knowing the Future. European Journal of International Relations, 13(1), 89-115. doi: 10.1177/1354066107074290.

Banulescu-Bogdan, N. \& Fratzke, S. (2015). Europe's Migration Crisis in Context: Why Now and What Next? Migration Policy Institute.

http://www.migrationpolicy.org/article/europe-migration-crisis-context-why-now-and-whatnext. Accessed 10 September 2016.

BBC Magazine (2015). Who, What, Why: What exactly is the UK's National Barrier Asset? http://www.bbc.co.uk/news/magazine-33316358. Accessed 10 September 2016.

BBC News (2015). David Cameron: "Swarm" of migrants crossing Mediterranean. http://www.bbc.co.uk/news/uk-politics-33714282. Accessed 10 September 2016.

Beck, U. (1986). Risk Society: Towards a New Modernity, Los Angeles, London, New Delhi and Singapore: Sage.

Beck, U. (1999). World Risk Society, Cambridge: Polity Press.

Bigo, D. (2014). The (in)securitization practices of the three universes of EU border control: Military/Navy - border guards/police - database analysts. Security Dialogue, 45(3), 209-225. doi: $10.1177 / 0967010614530459$

Bosworth, M. (2008). Border Control and the Limits of the Sovereign State. Social \& Legal Studies, 17(2), 199-215. doi: 10.1177/0964663908089611

Bosworth, M., \& Guild, M. (2008). Governing through migration control: Security and citizenship in Britain. British Journal of Criminology, 48(6), 703-719.

doi:10.1093/bjc/azn059

Cameron, D. (2014). HC Deb, 27 October, 2014, c23-34. Prime Minister, 23-34.

http://www.theyworkforyou.com/debates/?id=2014-10-

27b.23.0\&s $=$ calais + speaker\%3A10777\#g29.4. Accessed 10 September 2016.

Cameron, D. (2015a). Aid for Syria and EU Reform. Statement.

https://www.gov.uk/government/speeches/pm-statement-in-madrid-on-aid-for-syria-and-eureform. Accessed 10 September 2016.

Cameron, D. (2015b). Calais COBR meeting 31 July 2015: statement. Statement.

https://www.gov.uk/government/news/calais-cobr-meeting-31-july-2015-statement. Accessed 10 September 2016.

Cameron, D., 2015c. HC Deb, 19 October 2015, c655-672. 
http://www.theyworkforyou.com/debates/?id=2015-10-

19a.655.0\&s=calais + speaker\%3A10777\#g664.3. Accessed 10 September 2016.

Cameron, D. (2015d). HC Deb, 24 June., c876.

https://www.theyworkforyou.com/debates/?id=2015-06-

24a.876.5\&s=calais + speaker\%253A10777\#g877.1. Accessed 10 September 2016.

Cameron, D. (2015e). HC Debate, 17 November. Prime Minister, cc531-623.

http://www.theyworkforyou.com/debates/?id=2015-11-

17a.521.0\&s=calais + speaker\%3A10777\#g531.0. Accessed 10 September 2016.

Cameron, D. (2015f). Migration and EU Reform. Statement.

https://www.gov.uk/government/speeches/migration-and-eu-reform-pm-statement-in-lisbon. Accessed 10 September 2016.

Cameron, D. (2015g). Prime Minister Statement in Lebanon. Statement.

https://www.gov.uk/government/speeches/prime-minister-statement-in-lebanon. Accessed 10 September 2016.

Cameron, D. (2015h). Prime Minister's Speech on Europe. Chatham House [Speech]. https://www.gov.uk/government/speeches/prime-ministers-speech-on-europe. Accessed 10 September 2016.

Cameron, D. (2016a). HC Deb, 05 January, cc26. Prime Minister.

http://www.theyworkforyou.com/debates/?id=2016-01-

05d.26.0\&s $=$ calais + speaker\%3A10777\#g34.0. Accessed 10 September 2016.

Cameron, D. (2016b). HC Deb, 21 March, 2016, cc1250. Prime Minister, cc1250-126. http://www.theyworkforyou.com/debates/?id=2016-0321a.1244.0\&s=CALAIS+speaker:10777\#g1248.0. Accessed 10 September 2016

Cameron, D. (2016c). PM Statement following European Council Meeting. Statement. https://www.gov.uk/government/speeches/pms-statement-following-european-councilmeeting-19-february-2016. Accessed 10 September 2016.

Cendrowicz, L. (2015). Mediterranean migrant crisis: EU seeks UN approval for gunship plan and "use of force" to deter boats from Libya. Independent.

http://www.independent.co.uk/news/world/europe/mediterranean-migrant-crisis-eu-seeks-unapproval-for-gunship-plan-and-use-of-force-to-deter-boats-from-libya-10240241.html. Accessed 10 September 2016.

Cottle, S. (1998). Ulrich Beck, “ Risk Society” and the Media: View, A Catastrophic. European Journal of Communication, 13(1), 5-32.

Daddow, O. (2013). Margaret Thatcher, Tony Blair and the Eurosceptic Tradition in Britain. British Journal of Politics and International Relations, 15(2), 210-227.

Darian-Smith, E. (1999). Bridging Divides: The Channel Tunnel and English Legal Identity in the New Europe. Los Angeles: University of California Press.

https://books.google.co.uk/books?hl=en\&lr=\&id=Y1Z5AifU4EoC\&oi=fnd\&pg=PR9\&dq=bri dging + divides $+\% 2 \mathrm{~B}+$ darian\&ots $=$ lq2qVS6Pi4\&sig $=\mathrm{GYg1HwN}$ cSTtrmlxDBhdTh6OT4w\# $\mathrm{v}=$ onepage \& $\mathrm{q}=$ bridging divides $\% 2 \mathrm{~B}$ darian\&f=false. Accessed 10 September 2016.

Darlington, F., Norman, P. \& Gould, M. (2015). Health and internal migration. In D. P. Smith 
et al. (Eds.), Internal Migration: Geographical Perspectives and Processes. Ashgate, (pp. 113-128).

Dennison, J. \& Goodwin, M. (2015). Immigration, Issue Ownership and the Rise of UKIP. Parliamentary Affairs, 68(April), 168-187.

Dillon, M. (1995). Sovereignty and Governmentality: From the Problematics of the "New World Order" to the Ethical Problematic of the World Order. Alternatives: Global, Local, Political, 20(3), 323-368.

Douglas, M. \& Wildavsky, A. (1983). Risk and culture: An essay on the selection of technological and environmental dangers, Los Angeles: University of California Press.

Feakins, M. \& Białasiewicz, L. (2006). Trouble in the East: The New Entrants and Challenges to the European Ideal. Eurasian Geography and Economics, 47(6), 647-661.

Fekete, L., 2005. The deportation machine: Europe, asylum and human rights. Race \& Class, 47(1), 64-78.

Foucault, M., 2007. Security, Territory and Population: Lectures at the College de France, 1977-1978. New York: Palgrave.

Frontex, Risk Analysis.

http://frontex.europa.eu/intelligence/risk-analysis/.

Geddes, A., (2005). Getting the best of both worlds? Britain, the EU and migration policy. International Affairs, 81(4), 723-740.

Gower, M. \& Smith, B. (2015). Briefing Paper: Migration pressures in Europe. House of Commons Library, (CBF 7210).

http://researchbriefings.parliament.uk/ResearchBriefing/Summary/CBP-7210\#fullreport.

Accessed 10 September 2016

Green, D. (2010). Stowaways' sweet escape foiled by border officials. Home Office.

https://www.gov.uk/government/news/stowaways-sweet-escape-foiled-by-border-officials. Accessed 10 September 2016.

HC (2015a). Deb, 19 October 2015, cc655-.

http://www.theyworkforyou.com/debates/?id=2015-10-

19a.655.0\&s=calais + speaker:10777\#g664.3. Accessed 10 September 2016.

HC (2015b). Deb., 18 November, c665. http://www.theyworkforyou.com/debates/?id=201511-18a.664.11\&s=calais + speaker:10777\#g665.4. Accessed 10 September 2016.

Home Office (2010). Stowaways found on yacht.

https://www.gov.uk/government/news/stowaways-found-on-yacht. Accessed 10 September 2016.

Home Office, 2016. UK-France Summit: Annex on Migration.

https://www.gov.uk/government/uploads/system/uploads/attachment data/file/505175/UKFR S Migration 2 March.pdf. Accessed 10 September 2016.

Howarth, A. \& Ibrahim, Y. (2012). Threat and Suffering: The Liminal Space of "The Jungle". In H. Andrews \& L. Roberts, (Eds). Liminal Spaces. London: Routledge. 
Ibrahim, Y. \& Howarth, A. (2016a). Constructing the Eastern European Other: The Horsemeat Scandal and the Migrant Other. Journal of Contemporary European Studies, 2804(February), 1-17. doi: 10.1080/14782804.2015.1135108.

Ibrahim, Y. \& Howarth, A. (2016b). Contamination, Deception and "Othering": The Media Framing of the Horsemeat Scandal. Social Identities: Journal for the Study of Race, Nation and Culture, doi: 10.1080/13504630.2016.1207512.

Ibrahim, Y. \& Howarth, A. (2015). Sounds of the Jungle: Re-Humanizing the Migrant. $J O M E C, 7$. http://www.cardiff.ac.uk/jomec/research/journalsandpublications/jomecjournal/7 june2015/index.html. Accessed 10 September 2016.

Irwin, A. (2001). Sociology and the Environment: A critical introduction to society, nature and knowledge, London: Polity Press.

Legrain, P. (2015). Europe needs to let the migrants in. Foreign Policy (Blog). http://foreignpolicy.com/2015/08/24/europe-needs-stop-fear-mongering-and-let-migrantseconomy/. Accessed 10 September 2016.

Light, D. \& Young, C. (2009). European Union Enlargement, Post-Accession Migration and Imaginative Geographies of the "New Europe": Media Discourses in Romania and the United Kingdom. Journal of Cultural Geography, 26(3), 281-303.

May, T. (2011). HC Deb, 07 November, c44.

https://www.theyworkforyou.com/debates/?id=2011-11-07a.44.0. Accessed 10 September 2016.

May, T. (2014). Home Secretary launches new Border Force cutter to protect UK coastline. Home Office.

https://www.gov.uk/government/news/home-secretary-launches-new-border-force-cutter-toprotect-uk-coastline. Accessed 10 September 2016.

May, T. (2015a). Home Secretary statement on illegal immigration in Calais. Home Office. https://www.gov.uk/government/speeches/home-secretary-statement-on-illegal-immigrationin-calais. Accesssed 10 September 2016.

May, T. (2015b). Home Secretary's update on the migration situation in Europe and the Middle East. Home Office.

https://www.gov.uk/government/speeches/home-secretarys-update-on-the-migrationsituation-in-europe-and-the-middle-east. Accessed 10 September 2016.

May, T. (2015c). Joint action between the UK and France on migrant pressure. Home Office. https://www.gov.uk/government/news/joint-action-between-the-uk-and-france-on-migrantpressure. Accessed 10 September 2016.

May, T. (2015d). Joint action between the UK and France on migrant pressure. Home Office. https://www.gov.uk/government/news/joint-action-between-the-uk-and-france-on-migrantpressure. Accessed 10 September 2016.

Mortimer, C. (2015). Philip Hammond's demonization of "marauding" migrants is shameful, says Amnesty International. The Independent.

http://www.independent.co.uk/news/uk/politics/philip-hammonds-demonising-of-maraudingmigrants-comments-is-shameful-10447901.html?origin=internalSearch. Accessed 10 
September 2016.

O’Connor, S. \& Vina, G. (2016). What will Brexit mean for immigration? Financial Times. http://www.ft.com/cms/s/0/a874de26-34b2-11e6-bda0-04585c31b153.html. Accessed 10 September 2016.

Oxford Migration Observatory (2014). Calais and clandestine migration into the UK: Concerns and context. http://www.migrationobservatory.ox.ac.uk/commentary/calais-andclandestine-migration-uk-concerns-and-context. Accessed 10 September 2016.

Papademetriou, D. (2015). Top 10 of 2015 - Issue \# 1: Migration crisis tests European consensus and governance. Migration Policy Institute.

http://www.migrationpolicy.org/article/top-10-2015-issue-1-migration-crisis-tests-europeanconsensus-and-governance. Accessed 10 September 2016.

Pidgeon, N., Kasperson, R.E. \& Slovic, P. (2003). The social amplification of risk, Cambridge: Cambridge University Press.

Prothero, R.M., 2001. Migration and malaria risk. Health, Risk \& Society, 3(1), 19-38. doi: $10.1080 / 713670171$.

Sellar, C., Staddon, C. \& Young, C. (2009). Twenty years after the Wall: geographical imaginaries of "Europe" during European Union enlargement. Journal of Cultural Geography, 26(3), 253-258.

de Sherbinin, A. et al., (2012). Migration and risk: net migration in marginal ecosystems and hazardous areas. International Research Letters, 7, 1-14.

Somerville, W. (2016). Brexit: The Role of Migration in the Upcoming EU Referendum. The Migration Institute.

http://www.migrationpolicy.org/article/brexit-role-migration-upcoming-eu-referendum. Accessed 10 September 2016.

Taylor, M., Wintour, P. \& Elgot, J. (2015). Calais crisis: Cameron pledges to deport more people to end "swarm" of migrants. The Guardian. http://www.theguardian.com/uknews/2015/jul/30/calais-migrants-make-further-attempts-to-cross-channel-into-britain.

Accessed 10 September 2016.

UNHCR (2016). Global Trends Forced Migration report 2015, Geneva.

http://www.baag.org.uk/resources/unhcr-global-trends-forced-migration-report-2015-june-

2016. Accessed 10 September 2016.

UNHCR (2015a). High-level UN event tackles biggest refugee and migration crisis since Second World War, Geneva.

http://www.un.org/apps/news/story.asp?NewsID=52074\#.VnwXy1kSzAE. Accessed 10 September 2016.

UNHCR (2015b). Worldwide displacement hits all-time high as war and persecution increase.

http://www.unhcr.org/558193896.html. Accessed 10 September 2016.

Walklate, S. \& Mythen, G. (2015). Contradictions of Terrorism: Security, Risk and Resilience, New York: Routledge.

https://books.google.co.uk/books?hl=en\&lr=\&id=wieDBAAAQBAJ\&oi=fnd\&pg=PP1\&dq= 


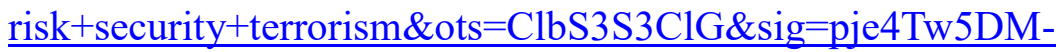

ualPRyP8Ru7XDn69A\#v=onepage \&q=risk security terrorism \&f=false. Accessed 10 September 2016.

Wall, S. (2012). Britain and Europe. The Political Quarterly, 83(2), 1191-1203. 